\title{
Enhancing Speaking Proficiency by Adapting Grammar- Translation Method And Electronic Dictionary For Young Learners
}

\author{
Edy Suseno, Edysuseno4@gmail.com, IKIP Widya Darma Surabaya, Pasca Sarjana \\ Universitas Negeri Surabaya \\ Oikurema Purwati, Oikuremapurwati@unesa.is.id, Pasca Sarjana Universitas Negeri \\ Surabaya
}

\begin{abstract}
The globalization is inviting people to learn English to communicate among the people around the world for any purpose. Fostering young learners to learn English is promising. It is a good start to build language proficiency. Nevertheless, teaching English, especially speaking for young learners, is challenging. They get difficulties expressing their idea due to the lack of vocabulary and grammatical problems. The research was conducting GTM implementation and electronic dictionary established to solve the problem. This research involved twenty students of fifth-graders performed for twenty opportunities, and each period took 90 minutes. The data found in this research pre-test and post-test were analyzed using a rubric and strengthen with a t-test. The result of this study is implementing GTM, and electronic dictionary enhances the development of speaking competence.
\end{abstract}

Keyword: Electronics dictionary; GTM; Podcast; Pronunciation; young learners

\section{INTRODUCTION}

In the digital era, people get involved in global communication for any reason, like a business, study, and many others (Al-Jarf, 2007). The presence of the internet in everyday life enables people to intensify their involvement in accessing a lot of information and interaction among users all around the globe (Nævdal, 2007). The number of people is very busy with their gadgets due to the Language used. The information on the internet mostly delivered was in English. English ranked on the ten top of the Language used in the world (Internet World Stats, 2006). Based on the research, English used two-third of the whole website (Reach, 2004). The use of English in ICT (information and communication technology) interferes with educational practice(Huchinson \& Waters, 1987).

The importance of English provokes many people to learn it. To prepare the young learners to compete with other people in any field, the government in many countries boosts the primary school stakeholders to facilitate the English teaching for the students (Graddol, 2006). The young learners are more comfortable to learn a new language than the older ones. Their ages are between 5 to 12 years old (Rixon \& Council, 1999).

Nevertheless, the aim of learning English is for communication among English users anywhere. Most of the students face a lot of problems in learning to speak. Even the learners had already learned it for many years (Bueno et al., 2006). Thornbury (2005) said that for teaching speaking, the teachers could implement three theories behaviorist, cognitivist, and sociocultural theory. In behaviorist, the learning process is focusing on the repeated drill

44 | IJET| Volume. 9, Issue 1. July 2020 Copyright 2020 Edy Suseno \& Oikurema Purwati are licensed under Creative Commons Atrribution-ShareAlike 4.0 International License. 
while in cognitivist, the teachers can lead the students to be autonomous by applying some methods. The last one is the sociocultural theory. In this theory, the teachers suggested digging some information concerning social and cultural activity to their students to extend it into the teaching-learning process. It is the so-called assisted performance.

Teaching speaking to young learners, teachers need to know the components that enhance the speaking learning process (Larsen-Freeman, 2000). Enhancement of the activity like pronunciation, intonation, and turn-taking in the teaching-learning process benefits the students to develop their speaking competence. That kind of learning can extend into questioning and answering activity (Ioannou-Georgiou, 2003). Moreover, teaching speaking needs to emphasize due to the use of Language (Scrivener, 2011).

Nevertheless, the tool to deliver ideas is words. Without the words, the intention cannot express into utterances (Thornbury, 2006). The strategy to learn vocabulary needs to be enhanced (Cameron, 2001). Showing the vocabulary list with the definition and pronunciation is often able to build the vocabulary knowledge in the students' heads (Nash $\&$ Donaldson, 2005). Activate the understanding of words into language use help the students better their ability in using Language as the communication tool (Nation, 2013). Focusing on teaching vocabulary, both the teachers and students can gain success in teaching-learning language (Walters, 2004).

The role of the dictionary in learning vocabulary dramatically impacts on the vocabulary building (Schmitt \& Schmitt, 2020). It leads the EFL students to depend on the dictionary usage inside and outside the classroom (Krashen, 2003). Concerning the type of dictionarylike monolingual and bilingual, the students can choose the desirable one (Hartmann, 2003). For the students in beginner or intermediate level tend to use the bilingual dictionary (Chen, 2011). Moreover, the influence of the development of technology provides the electronic dictionary for language users. The electronic dictionary embodied with the audio recording. It enables the students to copy the authentic pronunciation in communication practice(Nesi, 1999). The speed of service in the electronic dictionary to use for searching intended words for definition, pronunciation, and usage invites the students to use it anytime and anywhere (Laufer \& Hill, 2000). Al-Jarf (2007) said that Most of the students claim that the use of an electronic dictionary helps them develop their vocabulary knowledge at best. The presence of an electronic dictionary engages the students to learn to speak and to listen much better than using a paper dictionary (Wood, 2001). Moreover, using an electronic dictionary leads the students to be autonomous. They can correct their pronunciation for the intonation (AlSeghayer, 2005).

Interaction among the people is not just uttering the words. It is about how to say and how to understand the culture of the interlocutors (Brown, 2000). The speaking is the product of systematic verbal utterance to express the ideas. It is the activity used by people in daily life to exchange understandable information (Rapp \& Van Den Broek, 2005).

The way to express the ideas, many people implement the translation-method in their head from their mother tongue to target language and vice-versa to convey their intention to other people using a foreign language. Learning English by using a translation-method is used by EFL learners. They do not need the presence of native speakers to learn it (Bowen, 2013). The adoption of translation-method mostly used to teach grammar. It is the so-called grammar-translation method. It is the old method used by EFL learners a long time ago. Nevertheless, it is still used by the teachers in the classroom secretly and privately. Using

45 | IJET| Volume. 9, Issue 1. July 2020 Copyright 2020 Edy Suseno \& Oikurema Purwati are licensed under Creative Commons Atrribution-ShareAlike 4.0 International License. 
GTM is useful and helpful for both teachers and students, though (DELLER \& Rinvolucri, 2017).

The mother tongue is the mother of other languages. Through the use of the mother tongue, the students learn different words. It is the process of translation to gain the proficiency of other languages. Without the role of the mother tongue, the additional language learning is impossible to do. It is a natural process to happen in the learners' minds (DELLER \& Rinvolucri, 2017).

In the previous study, Bowen (2013) said that teaching grammar by using GTM is not hampering the students from learning speaking. It is the basic knowledge the students need to learn the communication both spoken and written. It is the way to construct sentences. To implement GTM trigger the students' ability to speak, the teacher can combine it with Communicative language teaching or CTL. It can be called the communicative grammartranslation method or CGTM. There are three steps in applying CGTM structural procedure, transitional procedure, and communicative procedure. In the fundamental process, the teacher discusses the grammar and vocabulary.

In contrast, in the interim procedure, the teacher allows the students to implement the translation method in adapting grammar usage into speaking practice. The last one is a communicative procedure. The teacher provokes the students to activate the use of their background knowledge in grammar and vocabulary in conversation.

Furthermore, Alam (2015) stated that the implementation of ELT in the classroom, the teachers applying the two methods GTM and CLT to gain the students' proficiency in speaking. This kind of combined-method used to teach English in a secondary school in Bangladesh. To apply it in the teaching-learning process, the teacher arranges the student's seats into some clusters. They interact with one another student based on the teacher's instruction. This kind of method enables the students to exchange information in English. Still, in the process of delivering ideas, they can use their mother tongue to gain the definition of English words and vice-versa.

The two previous studies emphasize the use of GTM and CLT in teaching speaking. The students and teachers synergize to enhance the practice of using GTM and CLT simultaneously. To gain the proper pronunciation, the two researchers did not mention the way to do. It needs an effort for the teachers to invite the students to use a particular method that enhances their proficiency in pronunciation.

Nevertheless, teaching speaking for young learners is inviting some difficulties. In some schools, they learn English for six years, but they still get challenges in delivering their intention in English. There must be problems for both the teachers and students face in teaching the learning process. Finding an approach to assist the students in gaining their proficiency in practicing speaking needs to be established.

The goal of this research is to prove the effectiveness of using an electronics dictionary to better speaking competence through the grammar-translation method to young learners. Through this study, it would see whether using an electronics dictionary brings the young learners to be autonomous when they find new words and phrases in speaking class. Moreover, the finding of this research could inspire other researchers to dig some profound results of related studies to gain innovations. 


\section{METHOD}

This kind of study conducted in primary school volunteered by twenty of the fifth graders. They deprived twelve females and eight males. To meet the goal of the study, the students joined twenty opportunities for treatment. Each period of the procedure took 90 minutes. There are three steps in completing the research before, during, and after the process.

\subsection{Before the treatment}

Before holding the treatment, the principle agreed to conduct research involving his fifth-graders. He also decided on the timetable of the activity and the use of the classroom. The reason for Choosing this level of participants is that they have sufficient opportunities for English study in their school. It enables them to observe their competency in speaking. The students have distributed the book to ease the treatment (Suseno, 2019). This book implements the GTM in learning grammar and communicative learning. The cover of the book shows figure 1 below.

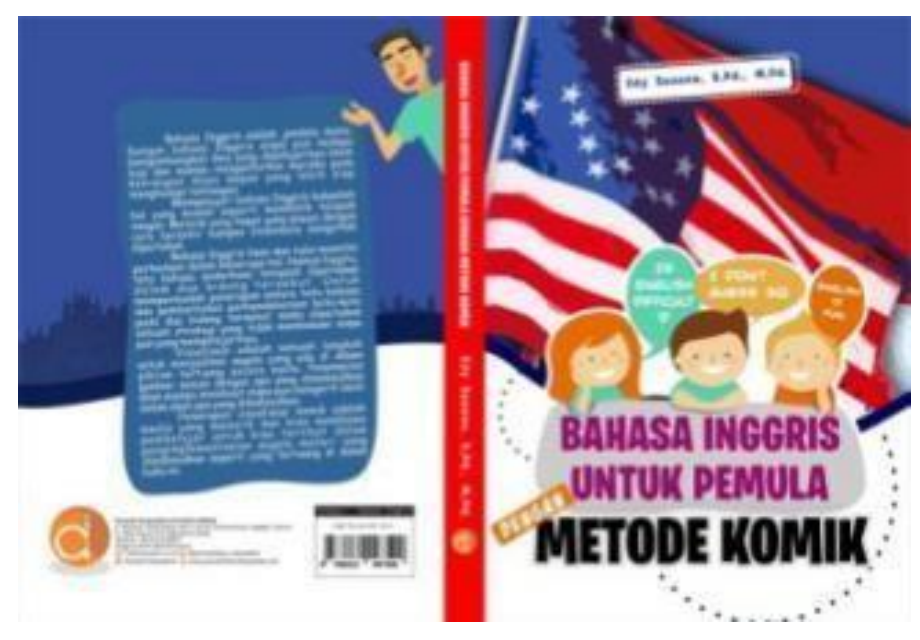

Figure 1.

The sample of the material, like the implementation of GTM, a list of vocabulary, and grammatical usage in communication, is significant to show. It can give a clear description of the intended material. There are samples of articles. They show figure 2, 3, and 4 below. 


\section{Vocabulary}

Pergunakan aplikasi untuk mendengarkan dan menirukan kata bahasa Inggris di bawah ini!

(A)

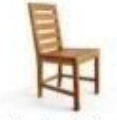

(B)

Chair $=$ Kursi

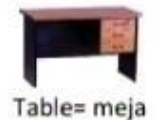

(C)

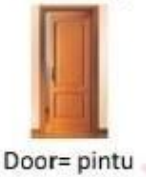

(D)

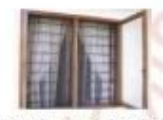

Window $=$ jendela

(E)

(F)

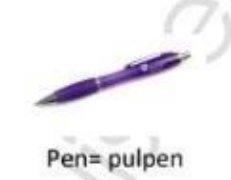

(G)

(H)

Book= buku

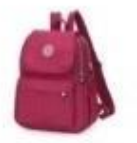

$\mathrm{Bag}=\operatorname{tas}$

(I)

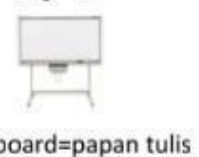

Whiteboard=papan tulis

pg. 4

Figure 2. The list of vocabulary 
Menerjemakan Kalimat

Ketiklah setiap jawaban di bawah pada aplikasi kemudian dengarkan dan tirukan!

This is = ini adalah

That is $=$ itu adalah

And $=$ dan

$A=$ sebuah, seekor

Contoh

Ini adalah sebuah tas dan itu adalah sebuah buku =

This is a bag and that is a book

Latihan 1

Kerjakanlah seperti contoh!

1. Ini adalah sebuah kursi=

2. Itu adalah sebuah meja=

3. Ini adalah sebuah kipas angin dan itu adalah sebuah papan tulis=

4. Itu adalah sebuah pulpen dan ini adalah sebuah buku=

5. Ini adalah sebuah tas dan itu adalah sebuah iendela $=$

Contoh

Folder $=$ map

(1)

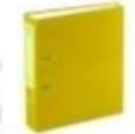

This ...is...........folder

pg. 5

Figure 3. GTM

49 | IJET| Volume. 9, Issue 1. July 2020

Copyright 2020 Edy Suseno \& Oikurema Purwati are licensed under Creative Commons Atrribution-ShareAlike

4.0 International License. 


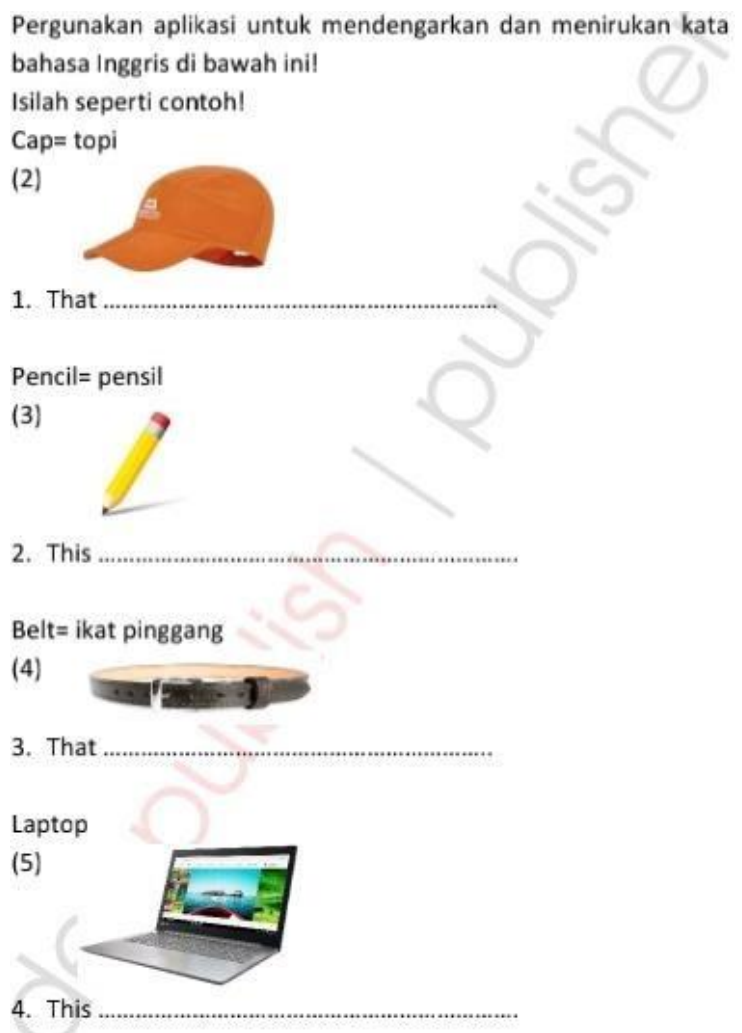

pg. 6

Figure 4. The implementation of GTM in communication

The students asked to check the pronunciation to adapt GTM into the conversation in their electronic dictionary to gain the proper pronunciation. It installed after distributing the books. To obtain such kind of dictionary, the students open the play store on their cellphone and write "Kamusku" to click. The form of the application shows fiure 5 below.

5. Coba tuliskan kata school lalu klik tanda speaker dan dengarkan.

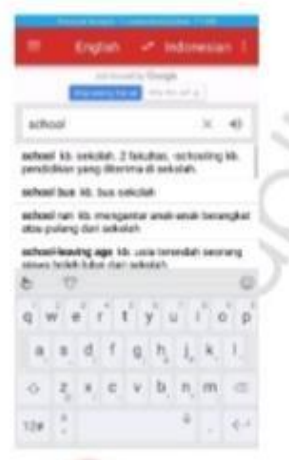

6. Lakukan untuk kata-kata lain yang dikehendaki.

Figure 5. The electronic dictionary 
Trying to be autonomous, the students need to adapt all the vocabulary and grammatical rules into the conversation. It helps them to adopt it in real life. They just fill the blank up and check the pronunciation of the words in their electronic dictionary, as seen in figure 6 . To make their works sound real, they need to practice them with their peers.

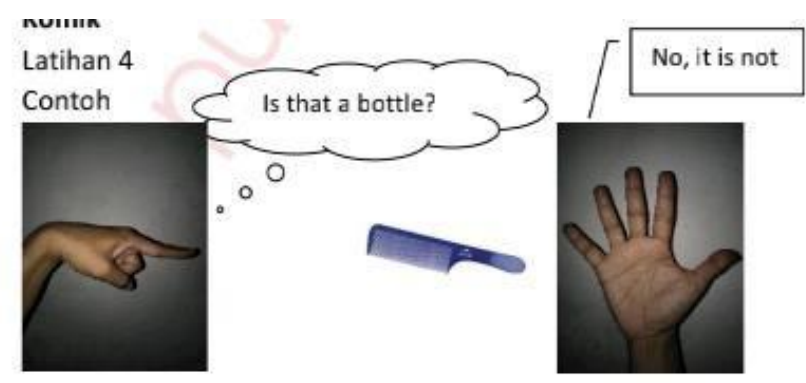

pg. 15

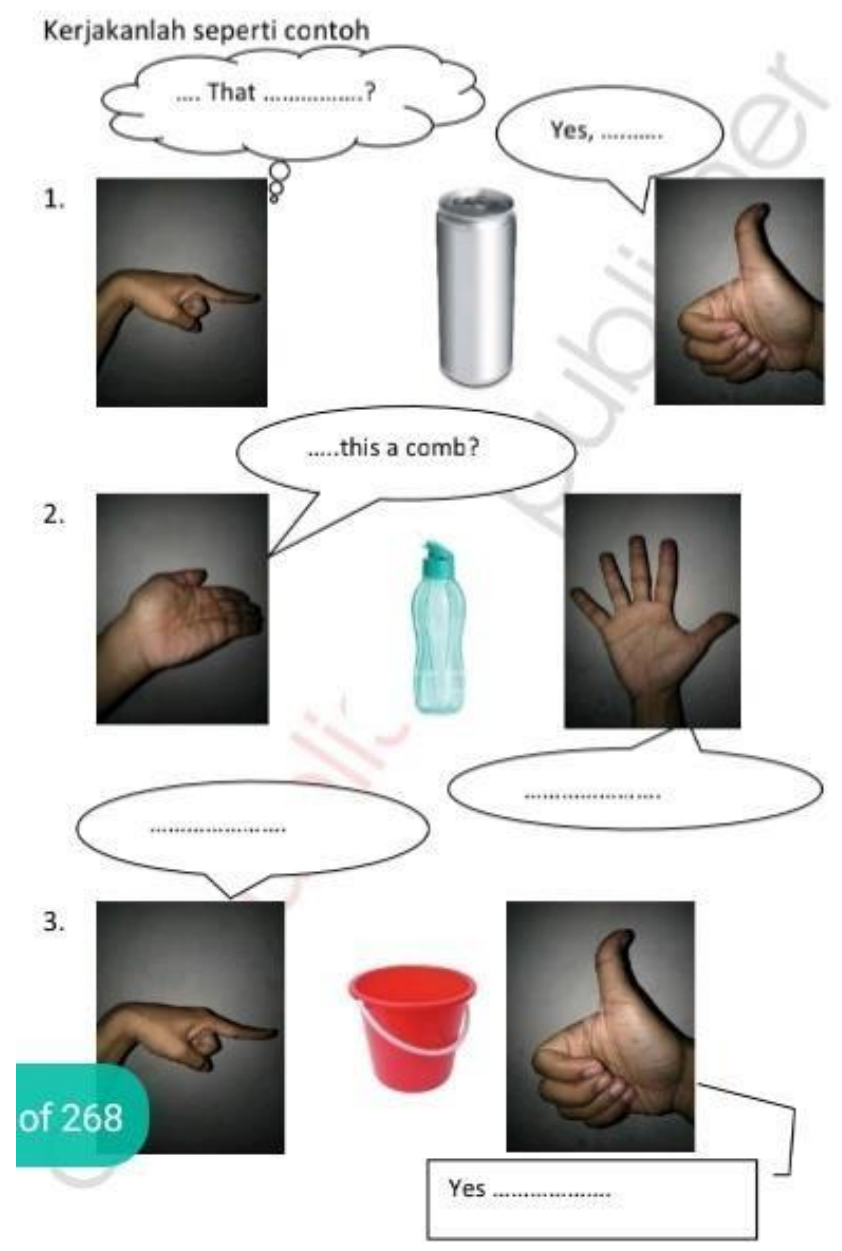

Figure 6. Adapting into conversation 
To ease the assessment of the students' oral task, the teacher created a Whatsapp group application. It leads the students to be internet literate. After distributing the books and installing the electronic dictionary that completed, the students joined the pre-test. This kind of test is in the interview to see the students' proficiency in speaking. The form of the interview shows below.

1. Answer the question below! (Interview)
a. Tell me about your family!
b. Tell me about your close friend
c. Tell me about some food you love to eat!
d. Tell me about your favorite subject! Why?
e. Tell me about something you love to do! Why?
f. Tell me about your favorite teacher! Why?
g. Tell me about your school!
h. $\quad$ Tell me about the animal you do not like! Why?
i. $\quad$ Tell me about your favorite color! Why?
j. Tell me about your house!

2. Describe the picture below as far as you could!

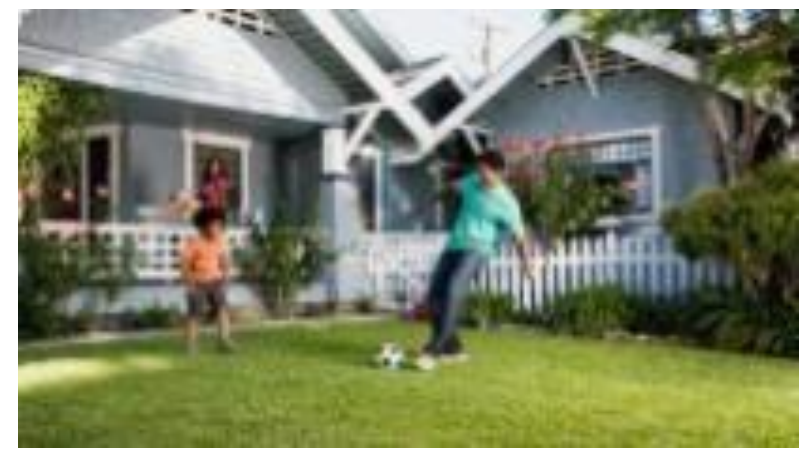

Figure 7. Describing picture

A rubric was adapted to fill the blank out of the assessment. There are some criterion need to be concerned. The scores arranged from 50 to 100 . The quality statements are very bad, bad, average, excellent, outstanding. The range between 50 to 59 categorized as very bad, $60-69$ is wrong, $70-79$ is average, $80-89$ is good, and $90-100$ is very good. There are three forms of rubrics the vocabulary, the intonation, and the speaking fluency, as seen below.

Table 1. The rubric of Choosing Words

\begin{tabular}{ccc}
\hline N & $\begin{array}{c}\text { Range of } \\
\text { Description } \\
\text { Scores }\end{array}$ & Description \\
\hline 1 & $\begin{array}{c}50-59: \text { Very } \\
\text { bad }\end{array}$ & $\begin{array}{l}\text { The students get difficulties to find the right } \\
\text { words in conveying intentions. And their } \\
\text { utterances are dominated by a very long pause to } \\
\text { say one or two words. }\end{array}$ \\
\hline 2 & 60-69: Bad & $\begin{array}{l}\text { The students get difficulties to find the right } \\
\text { words in conveying intentions. And their } \\
\text { utterances are dominated by the long pauses } \\
\text { while saying three or more words. }\end{array}$ \\
\hline
\end{tabular}

52 | IJET| Volume. 9, Issue 1. July 2020 Copyright 2020 Edy Suseno \& Oikurema Purwati are licensed under Creative Commons Atrribution-ShareAlike 4.0 International License. 


\begin{tabular}{cc}
\hline $\begin{array}{c}70-79: \\
\text { Average }\end{array}$ & $\begin{array}{l}\text { The students do not experience too much } \\
\text { difficulty in finding the right words to convey } \\
\text { their intention. Their utterances are dominated } \\
\text { by some pauses while saying three or more } \\
\text { words. }\end{array}$ \\
\hline $450-89:$ Good & $\begin{array}{l}\text { The students do not experience problems in } \\
\text { choosing the right words to convey their } \\
\text { intention, but it takes a few moments to } \\
\text { remember the words they had learned. It causes } \\
\text { some improper pauses among their terms. }\end{array}$ \\
& $\begin{array}{l}\text { The students do not have any problems all all } \\
\text { in choosing the right words to convey their } \\
\text { intention and putting the proper pauses in the } \\
\text { conversation. }\end{array}$ \\
\hline 5
\end{tabular}

Table 2. The rubric of Properness of the Intonation

\begin{tabular}{ccc}
\hline No & $\begin{array}{c}\text { Range of } \\
\text { Description } \\
\text { Scores }\end{array}$ & Description \\
\hline $\begin{array}{c}50-59: \text { Very } \\
\text { bad }\end{array}$ & $\begin{array}{c}\text { The students are only able to say one } \\
\text { or two words with a tone of voice that } \\
\text { does not lead to a specific purpose. }\end{array}$ \\
\hline 2 & $\begin{array}{c}\text { The students get difficulties to find } \\
\text { the right words in uttering three or more } \\
\text { words with a tone of voice that does not } \\
\text { lead to a specific purpose. }\end{array}$ \\
\hline 3 & $\begin{array}{l}\text { The students can say one or two } \\
\text { words with a tone of voice that leads to } \\
\text { a specific purpose. }\end{array}$ \\
\hline 5 & $\begin{array}{l}\text { The students can say three or more } \\
\text { words with a tone of voice that leads to } \\
\text { a specific purpose. }\end{array}$ \\
\hline 5 & $\begin{array}{l}\text { The students put the intonation of the } \\
\text { words, phrases, and } \\
\text { accordingly. }\end{array}$ \\
\hline
\end{tabular}

Table 3. The rubric of Speaking Fluency

\begin{tabular}{ccc}
\hline No & $\begin{array}{c}\text { Range of } \\
\text { Description } \\
\text { Scores }\end{array}$ & Description \\
\hline $\begin{array}{c}50-59: \text { Very } \\
\text { bad }\end{array}$ & $\begin{array}{c}\text { The students pronounce the words or } \\
\text { phrases with great difficulty regarding the } \\
\text { choice of words, intonation, and } \\
\text { constructing sentences. }\end{array}$ \\
\hline 2 & $60-69:$ Bad & The students pronounce the words or \\
\hline
\end{tabular}

53 | IJET| Volume. 9, Issue 1. July 2020 


\begin{tabular}{|c|c|c|}
\hline & & $\begin{array}{l}\text { phrases by experiencing a few difficulties } \\
\text { in choosing the words, intonation, and } \\
\text { constructing sentences. }\end{array}$ \\
\hline 3 & $\begin{array}{l}\text { 70-79: } \\
\text { Average }\end{array}$ & $\begin{array}{l}\text { The students pronounce the words or } \\
\text { phrases with no difficulty regarding the } \\
\text { choice of words, intonation, and } \\
\text { constructing sentences, but they take some } \\
\text { pauses to convey their opinion. }\end{array}$ \\
\hline 4 & 80-89: Good & $\begin{array}{l}\text { The students pronounce the words or } \\
\text { phrases with no difficulty regarding the } \\
\text { choice of words, intonation, and } \\
\text { constructing sentences, although with a } \\
\text { few improper pauses. }\end{array}$ \\
\hline 5 & $\begin{array}{r}\text { 90-100: } \\
\text { Very Good }\end{array}$ & $\begin{array}{l}\text { The students pronounce the words or } \\
\text { phrases with no difficulty regarding the } \\
\text { choice of words, intonation, and } \\
\text { constructing sentences at the proper pauses } \\
\text { and speed. }\end{array}$ \\
\hline
\end{tabular}

\subsection{During the treatment}

In the first learning, the teacher asked the students to open their books about grammar review. He explains the use of the grammar rule to construct sentences. He gave the example of the sentences by translating the sentences from Bahasa Indonesia into English, as seen in figure 3. It is the implementation of using the grammar-translation method to explain the grammar rules and its usage in two languages Bahasa Indonesia and English. It discusses the word and sentence structure (Evans, 2006).

Before assigning the exercises, the teacher asked the students to read the given vocabulary in the book after him, as seen in figure 2 . Some pictures of vocabulary are provided for the students to help them get a vivid understanding of the intended words. Through the photographs, the students remember the concepts they learn in their head everlasting (Carpenter \& Olson, 2012).

The vocabulary list used to complete the exercises. It is the way to put the proper words to implement the grammar rule into communication, as seen in figure 4. It makes

vocabulary meaningful. It helps the students choose the appropriate words to build intended sentences. The students feel confident to engage in conversation with other people by having a clear definition of the word in their vocabulary knowledge. The grammar, though, combines the words to form sentences (Rapp \& Van Den Broek, 2005).

After finishing all the tasks, the teacher discussed them with the students about their works. To make the vocabulary and grammar run automatically, the teacher asked the students to fill the pictures' blank out by writing them on their book and check them on their electronic dictionary for the pronunciation, as seen in figure 5. It leads the students to build their listening and pronunciation skills to fluent their speaking ability. The tool provided the meaning and the recording of the pronunciation words uttered by a native speaker (Singleton, 2016).To ensure the properness of the students' works, the teacher asked them to read and record them on their Whatsapp group. The teacher assesses all the submissions by giving feedback. Each period of the treatment has a similar pattern to do. The students guided to be autonomous. They can find the meaning of the unfamiliar words in the electronic dictionary freely in both definitions and pronunciation. It builds their autonomy in learning English to adopt in everyday life. The use of this kind of tool can 
use for written and spoken needs (Tananuraksakul, 2015).

\subsection{After the treatment}

After completing 20 opportunities for the treatment, the students joined the posttest. The question in the post-test is similar to the one in the pre-test. By assessing related items, the students' achievements can be measured. The scores found in the pre-test and post-test analyzed by using a rubric to see the picture of progress gained by the students after joining 20 opportunities for treatment. A t-test conducted to confirm the result. The analysis of this research used a mixed-method to meet the goal of the study.

\subsection{Finding}

By conducting this kind of research, the students did two types of tests pre-test and post-test. They are the tools to measure the students' competence in speaking both before and after the treatment. The rubric assessment established was to fill out the blank of the evaluation. It is the guidance to grade the students' ability to practice speaking. To see the scores of the students' speaking competence before joining the treatment can be seen below.

Table 4. Pre-test

\begin{tabular}{|c|c|c|c|c|}
\hline No & Fluency & Intonation & Vocabulary & Average \\
\hline 1 & 52 & 51 & 53 & 52 \\
\hline 2 & 58 & 59 & 58 & 58,33333 \\
\hline 3 & 57 & 58 & 59 & 58 \\
\hline 4 & 54 & 53 & 54 & 53,66667 \\
\hline 5 & 56 & 54 & 54 & 54,66667 \\
\hline 6 & 58 & 57 & 58 & 57,66667 \\
\hline 7 & 59 & 58 & 57 & 58 \\
\hline 8 & 53 & 52 & 51 & 52 \\
\hline 9 & 55 & 54 & 55 & 54,66667 \\
\hline 10 & 57 & 58 & 59 & 58 \\
\hline 11 & 53 & 52 & 51 & 52 \\
\hline 12 & 54 & 54 & 53 & 53,66667 \\
\hline 13 & 59 & 57 & 57 & 57,66667 \\
\hline 14 & 51 & 53 & 53 & 52,33333 \\
\hline 15 & 52 & 52 & 53 & 52,33333 \\
\hline 16 & 59 & 58 & 58 & 58,33333 \\
\hline 17 & 55 & 54 & 55 & 54,66667 \\
\hline 18 & 58 & 56 & 57 & 57 \\
\hline 19 & 52 & 51 & 52 & 51,66667 \\
\hline 20 & 57 & 58 & 57 & 57,33333 \\
\hline Average & 55,45 & 54,95 & 55,2 & 55,2 \\
\hline
\end{tabular}

After completing 20 opportunities for the treatment, the students joined the post-test. It is the way to see if the students get the progress or not. It also measures the level of achievement 
if the students develop their competence in speaking. Moreover, the description in the rubric enhances the clarity of the ability of the students. The scores of the pre-test can show at the table below.

Table 5. The post-test

\begin{tabular}{|c|c|c|c|c|}
\hline No & Fluency & Intonation & Vocabulary & Average \\
\hline 1 & 82 & 83 & 82 & 82,3333 \\
\hline 2 & 84 & 83 & 85 & 84 \\
\hline 3 & 92 & 90 & 91 & 91 \\
\hline 4 & 81 & 80 & 82 & 81 \\
\hline 5 & 79 & 78 & 79 & 78,6667 \\
\hline 6 & 83 & 80 & 82 & 81,6667 \\
\hline 7 & 85 & 83 & 85 & 84,3333 \\
\hline 8 & 86 & 86 & 87 & 86,3333 \\
\hline 9 & 88 & 86 & 90 & 88 \\
\hline 10 & 81 & 80 & 80 & 80,3333 \\
\hline 11 & 84 & 83 & 84 & 83,6667 \\
\hline 12 & 86 & 82 & 86 & 84,6667 \\
\hline 13 & 80 & 77 & 81 & 79,3333 \\
\hline 14 & 83 & 80 & 84 & 82,3333 \\
\hline 15 & 82 & 81 & 83 & 82 \\
\hline 16 & 84 & 82 & 83 & 83 \\
\hline 17 & 86 & 85 & 87 & 86 \\
\hline 18 & 81 & 80 & 82 & 81 \\
\hline 19 & 80 & 77 & 78 & 78,3333 \\
\hline 20 & 77 & 75 & 77 & 76,3333 \\
\hline Average & 83,2 & 81,55 & 83,4 & 82,71667 \\
\hline
\end{tabular}

\section{RESULT}

\subsection{Pre-test}

There are three categories in the pre-test vocabulary, intonation, and fluency. The data found by establishing an interview before joining the treatment. The description in the rubric to see the definition of the scores stated in the table can be adapted. The graph below shows the students' scores in vocabulary knowledge. It gives the illustration of the gain of each student.

Chart 1. Vocabulary building 


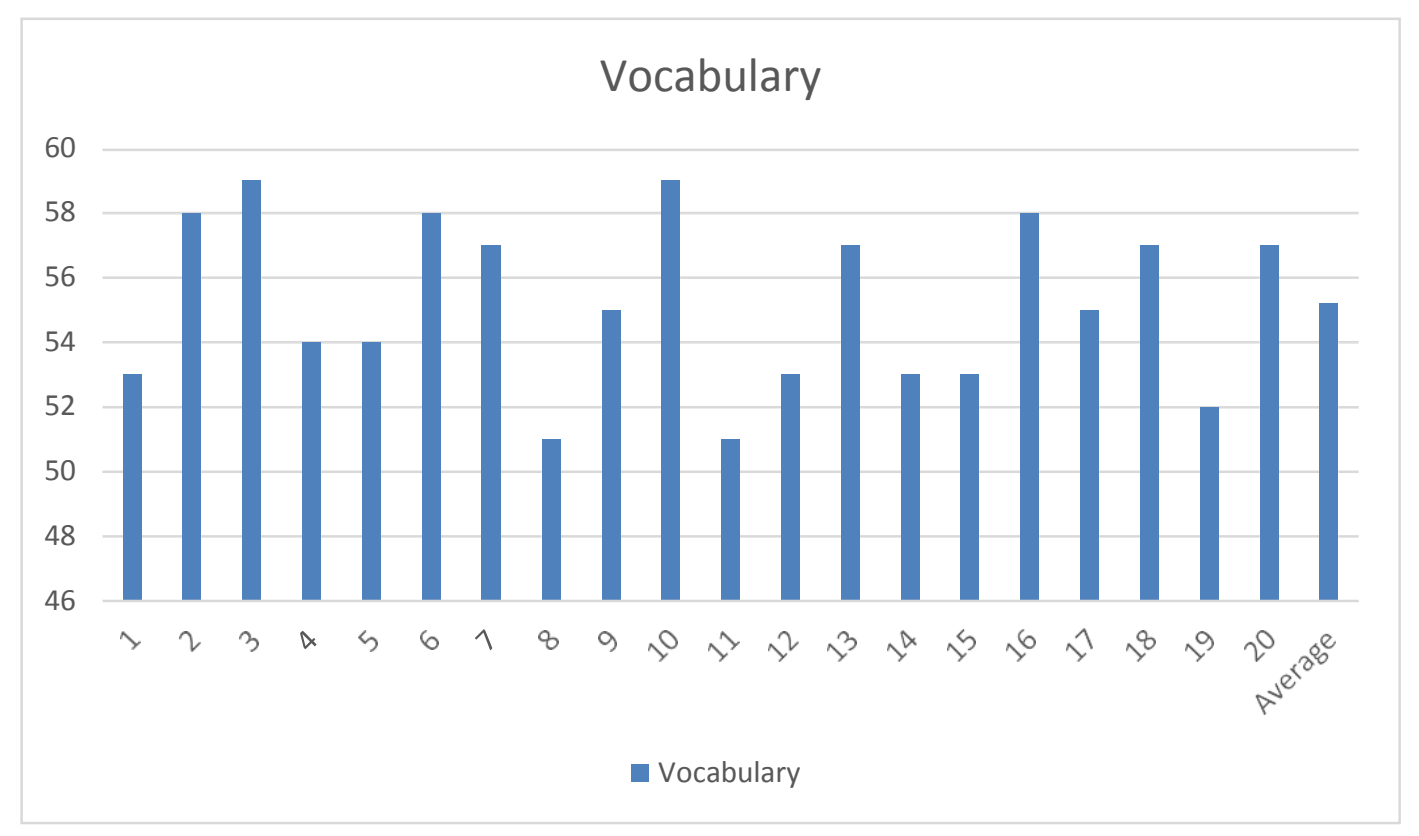

From the illustration above, it shows that the range of the scores is from 51 to 59. In that kind of scale, it categorized as very bad based on the vocabulary rubric. It means that the students' competence in choosing words while interacting with other people is very bad. The rubric states that terrible criteria indicate that the students got a problem with uttering their intention. They were just able to say one or two words with a long pause to remember the intended concepts. It leads the students to hamper their aim to deliver their ideas to other people.it is inline with August et al.'s (2005) idea. They said that the EFL learners who have insufficient words to utterance tend to be lack of involvement in communication with their peers. Therefore, to lead them to be optimistic in practicing speaking, they need to be enhanced to develop their vocabulary building.

Chart 2. Adapting the proper intonation

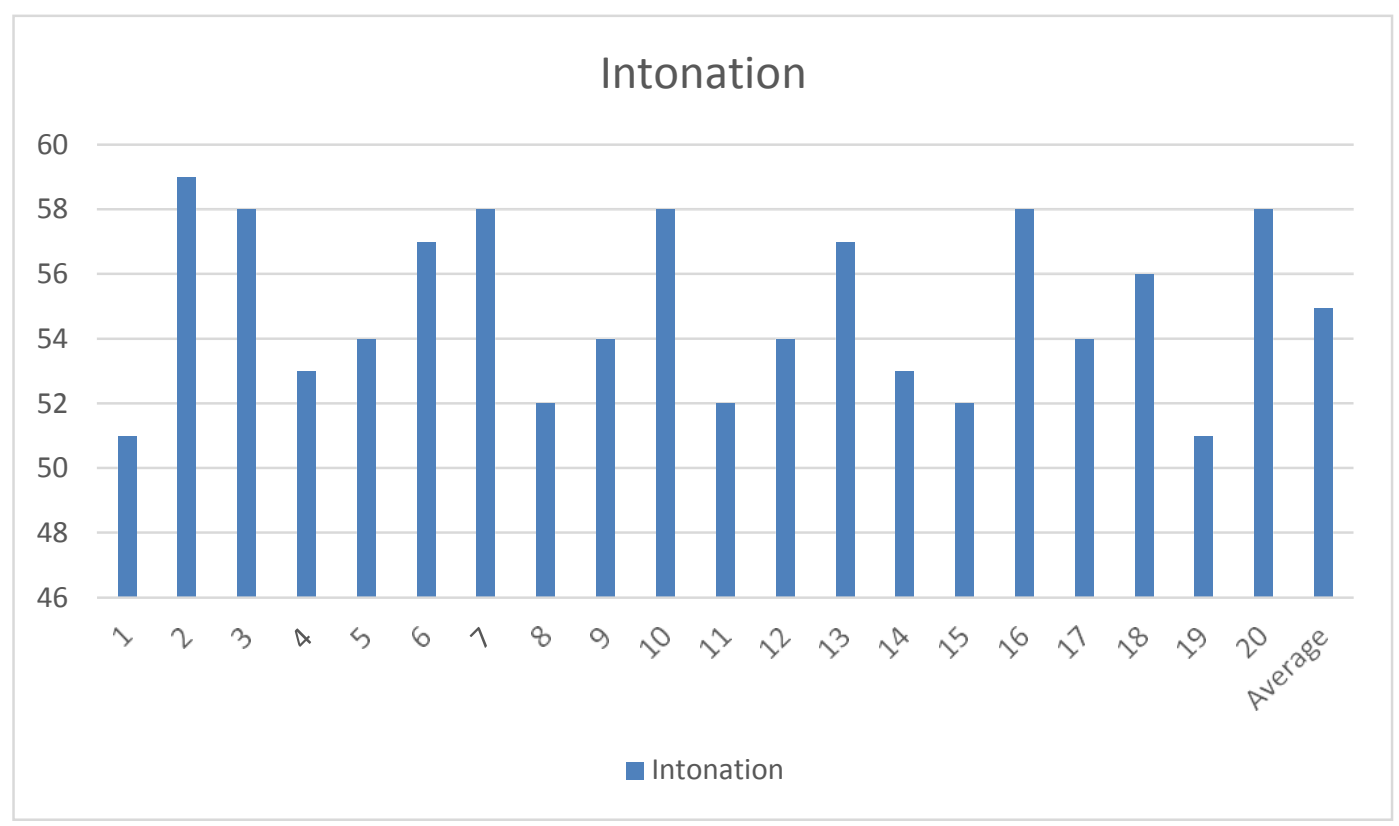

57 | IJET| Volume. 9, Issue 1. July 2020 Copyright 2020 Edy Suseno \& Oikurema Purwati are licensed under Creative Commons Atrribution-ShareAlike 4.0 International License. 
The questions in the interview revealed the students' ability to adapt the proper intonation. The intonation of the words has a very close relationship with the tone. It is about the melody of pronouncing words. The stressing the sound of the syllable in each word is different. Putting the proper pitch of the sound in the words, phrases, and sentences can lead to a particular meaning. Raising the last syllable of them, for example, can lead them to the interrogative intention. The students categorized as very bad based on adapting the proper intonation rubric to adopt the adequate intonation in responding to the question. In this category, the students described as a misleading intention by saying one or two words with an improper tone, like putting a pitch in the last of the syllable to make a confirmation. It can show in graph 2. Their scores vary from 51 to 59, with an average of 54.9. It seems that the students need some drills to better their intonation adoption. It is inline with Florez's (1998) opinion. He said that the students could teach to discriminate and produce the target sound by adapting some drills.

Chart 3. Speaking Fluency

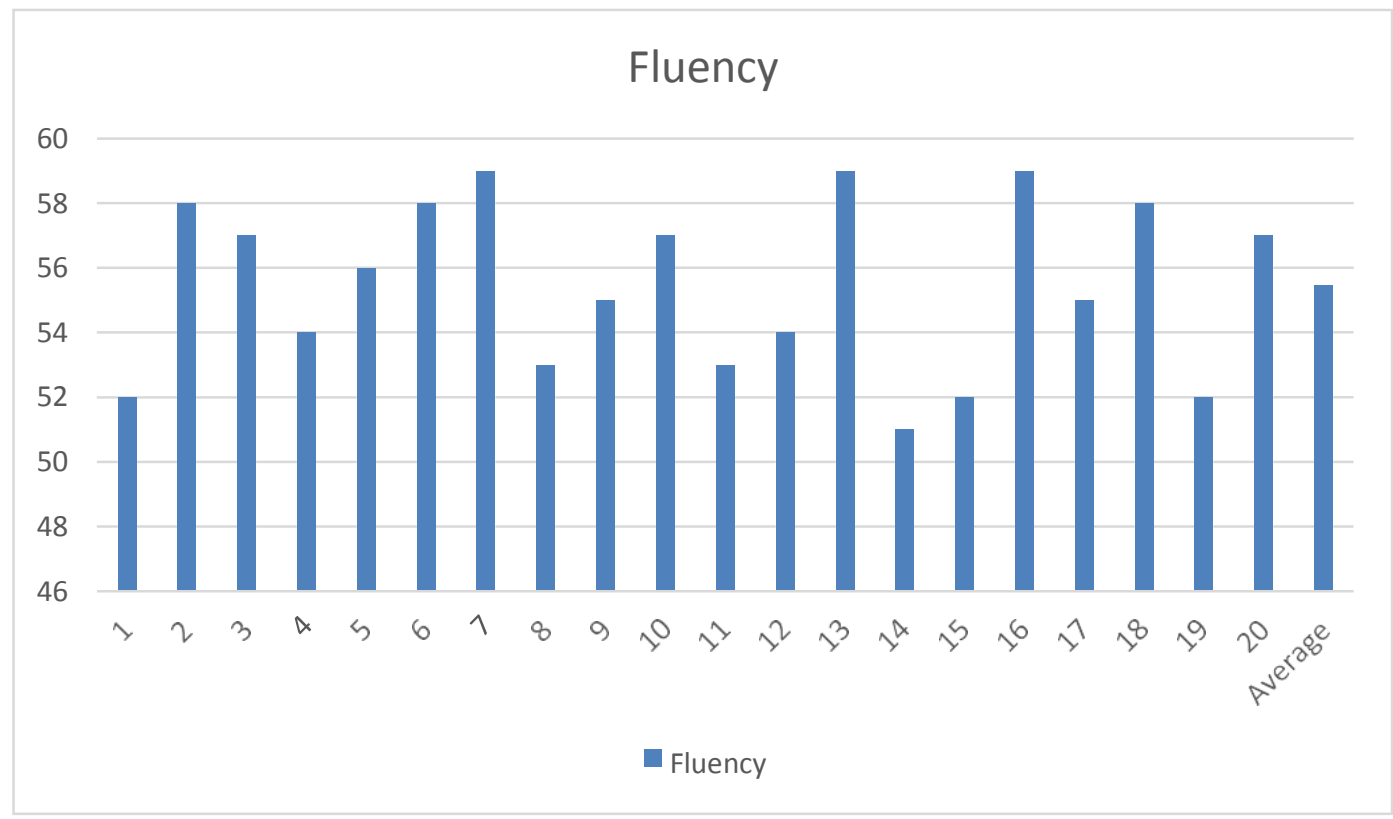

Brown (2004) said that speakers need to be able to produce, conceive, and process the information to convey meaningful utterances. It means that the speakers need to construct sentences regarding grammar, pronunciation, and choosing proper words and phrases to gain the smooth flow of speaking of fluency. In responding to the interview, the students could not reach the fluency of speaking. They got difficulty in uttering the proper words and arrange meaningful sentences. Based on the speaking fluency rubric, this kind of achievement categorized as very bad. The range of their scores is between $51-59$, with an average of 54.4, as seen in graph 3. They need to develop their fluency to make their utterances smooth and understandable.

\subsection{Post-test}

The 20 opportunities of the treatment need to assess. The participants followed each step of the procedures very well. They did not miss a single chance to take part in the process. The post-test conducted to see the development of their competence in speaking. This kind of test is similar to the one in the pre-test. It is the way to measure the level of progress the students made after joining the treatment. There are three categories assessed vocabulary building, 
intonation adaptation, and speaking fluency. The illustration of the pre-test scores shows in the graph below.

Chart 4. Vocabulary building

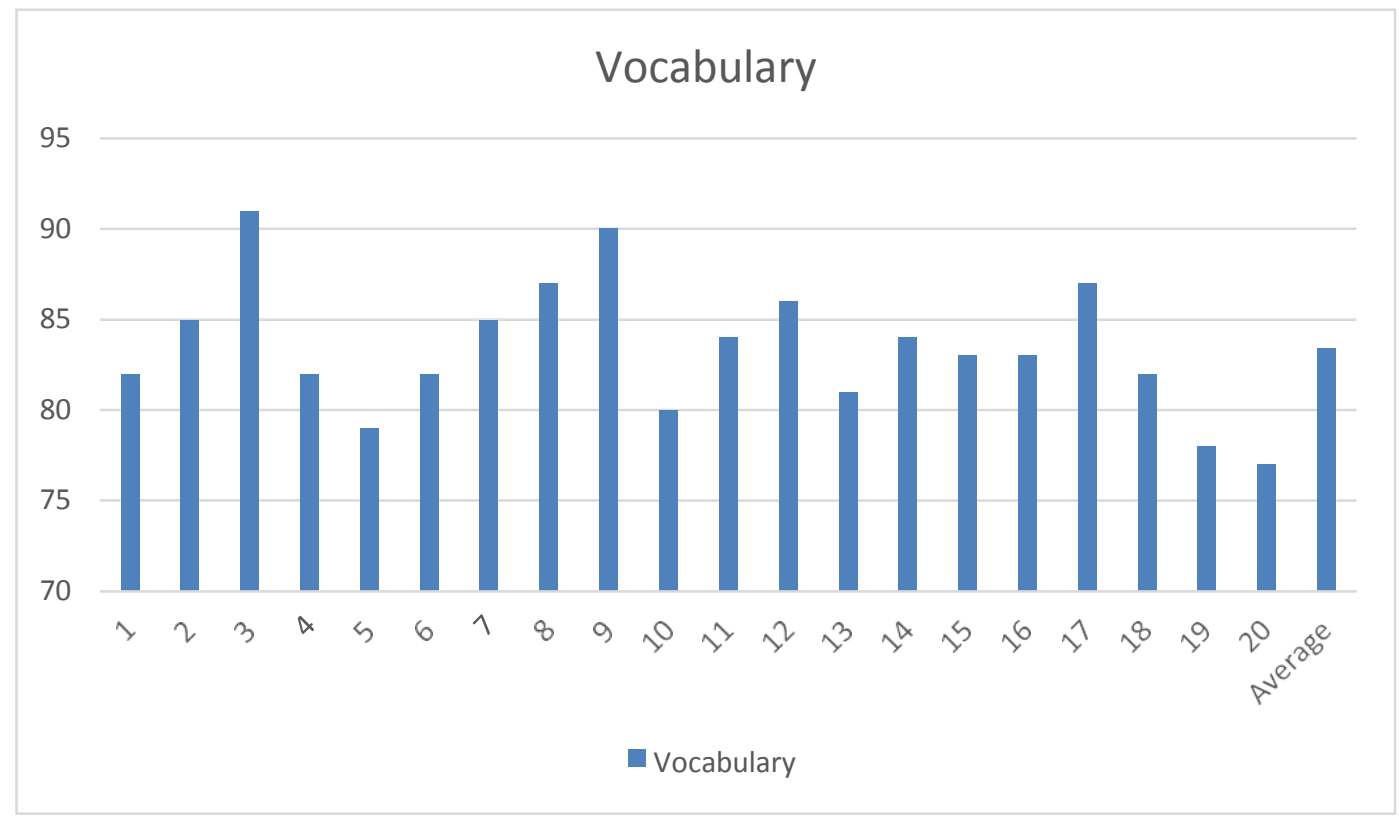

After a certain period of treatment, the students' competence in vocabulary building gets the progress. Their post-test scores in choosing words, as seen in graph 4, are between 77 to 91 , with an average of 82.7. Based on the rubric of vocabulary building, it categorized as useful. It stated that the students do not experience any problems in choosing the right words to convey their intention, but it takes a few moments to remember the words they had learned. Thus, some improper pauses happen. It means that their vocabulary knowledge is sufficient to conduct a conversation with other people. It is a kind of reflection from the learning process during the treatment. Providing vocabulary in the book helps the students develop their word list in their heads. Using the vocabulary input into some exercises make the students able to use them in the right condition.

Nevertheless, they still need some other treatment to gain the optimum result. It is inline with Cook's (2013) opinion. He said that the role of vocabulary in delivering meaningful utterances is significant to reach a mutual understanding among language users.

Chart 5. Adapting the proper intonation 


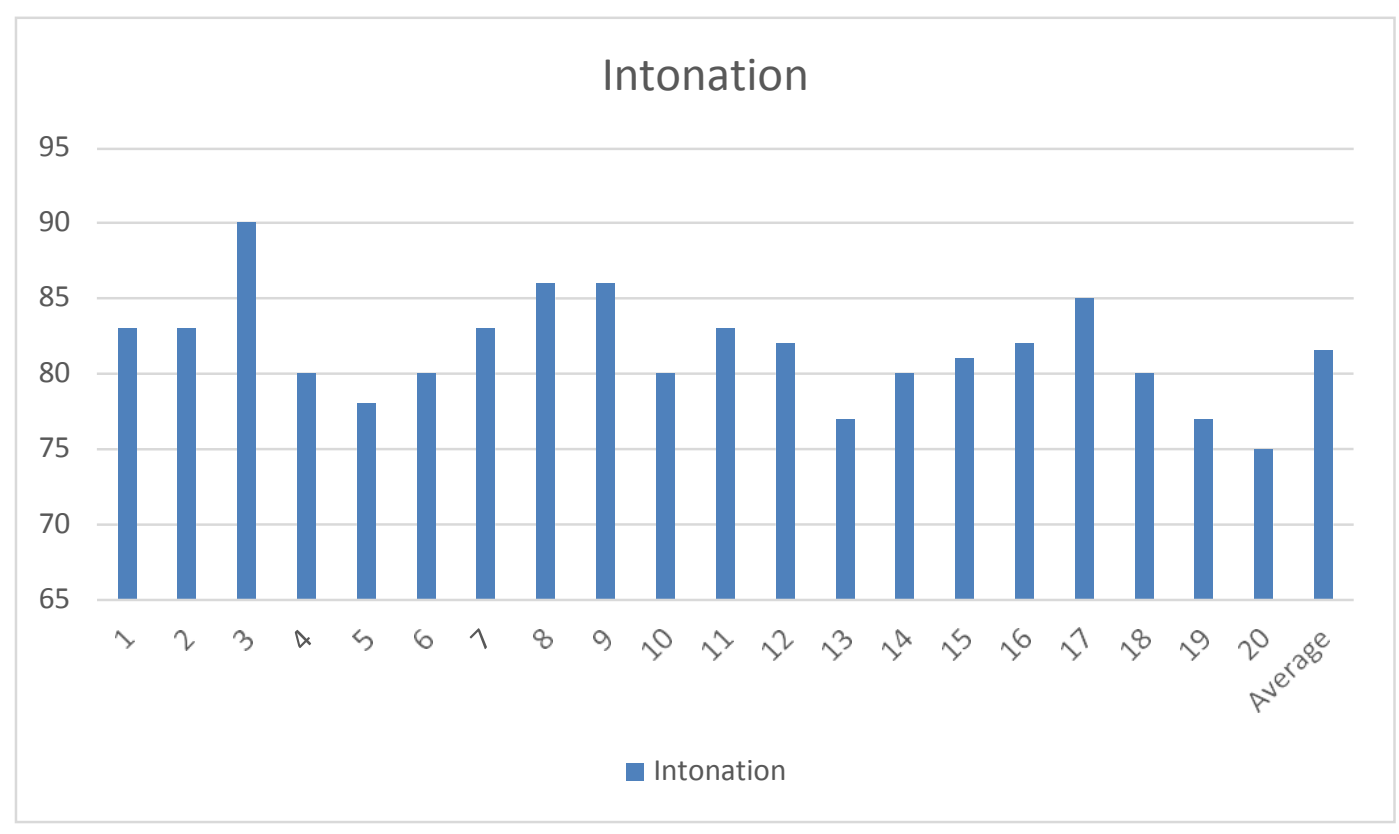

Using an electronic dictionary benefits the students to get the appropriateness of pronunciation. It also helps the students produce proper intonation of the words. Ellis (2003) said that learning the audio of the native speakers enables the learners to adapt it in real condition of conversation to reach the mutual understanding among the parties. During the treatment, the students used their electronic dictionary. It leads them to get the scores between 75 to 90 with an average of 81.6, as seen in graph 5. Based on applying the intonation rubric, it told that the first category describes the students' ability to place the proper intonation in uttering three or more words. Moreover, the students need to develop their competencies in setting anadequatetone on phrases and sentences to gain the smooth process of exchanging the information with other people.

Chart 6. Speaking Fluency

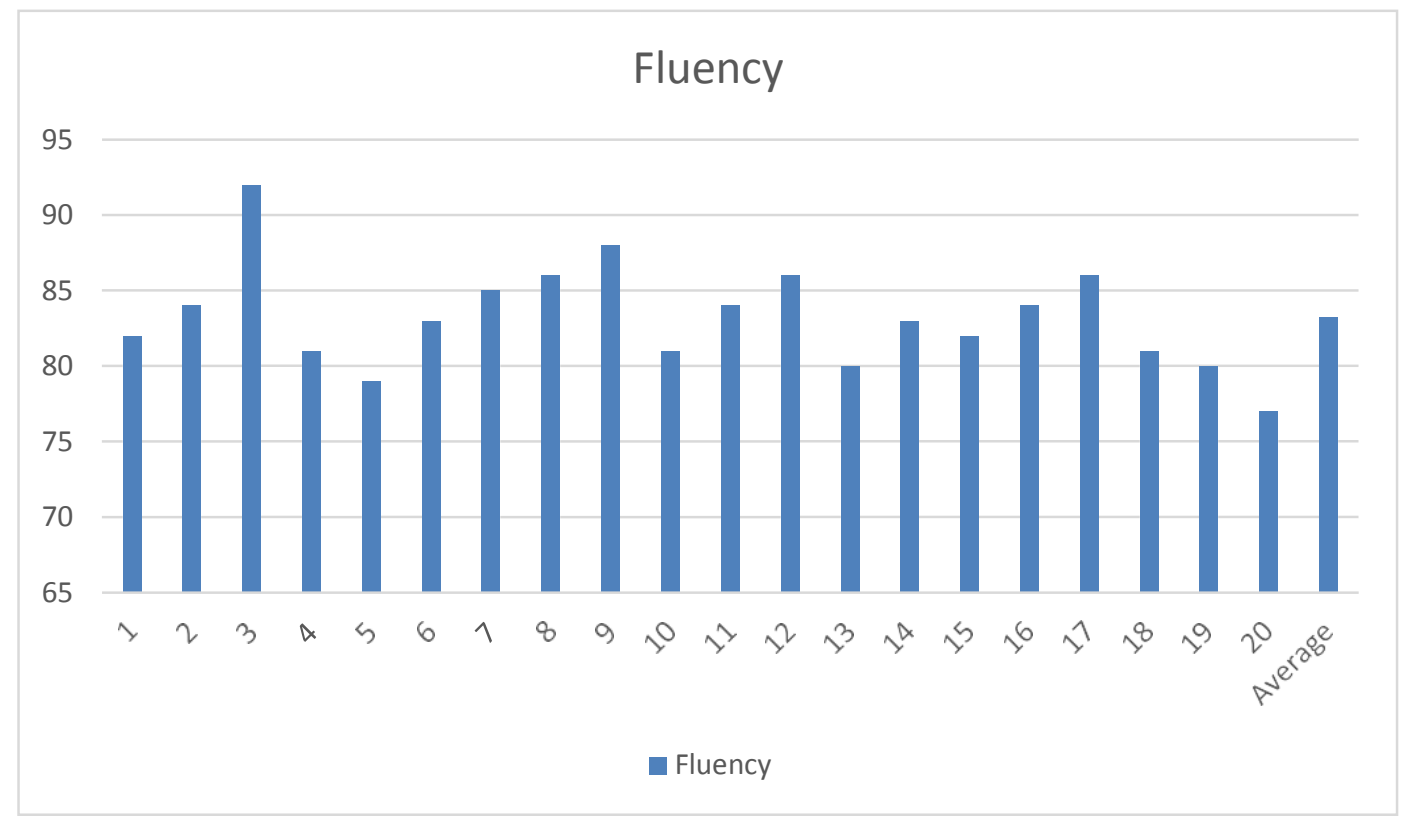

60 | IJET $\mid$ Volume. 9, Issue 1. July 2020 Copyright 2020 Edy Suseno \& Oikurema Purwati are licensed under Creative Commons Atrribution-ShareAlike 4.0 International License. 
The speaking fluency refers to the competence in choosing words, grammatical usage, pronunciation practice, and the smooth and speed of speech. By having such kind of expertise, the students can speak native speakers like by speaking less silent pauses, filled pauses, selfcorrection, self starts, and hesitations (Stockdale, 2009). Through the number of treatments, the students achieve some abilities in delivering ideas. By watching graph 6 , it shows that the students' scores in speaking fluency vary from 77 to 92 , with an average of 83 . Based on the speaking fluency rubric, this kind of score categorized as useful. It means that The students utter the words or phrases with no difficulty regarding the vocabulary, intonation, and constructing sentences, although with a few improper pauses. The students still need to develop their proficiency in speaking to gain the optimum result.

\subsection{The progress}

Chart 7. The average scores of vocabulary, intonation, and fluency in pre-test and post-test

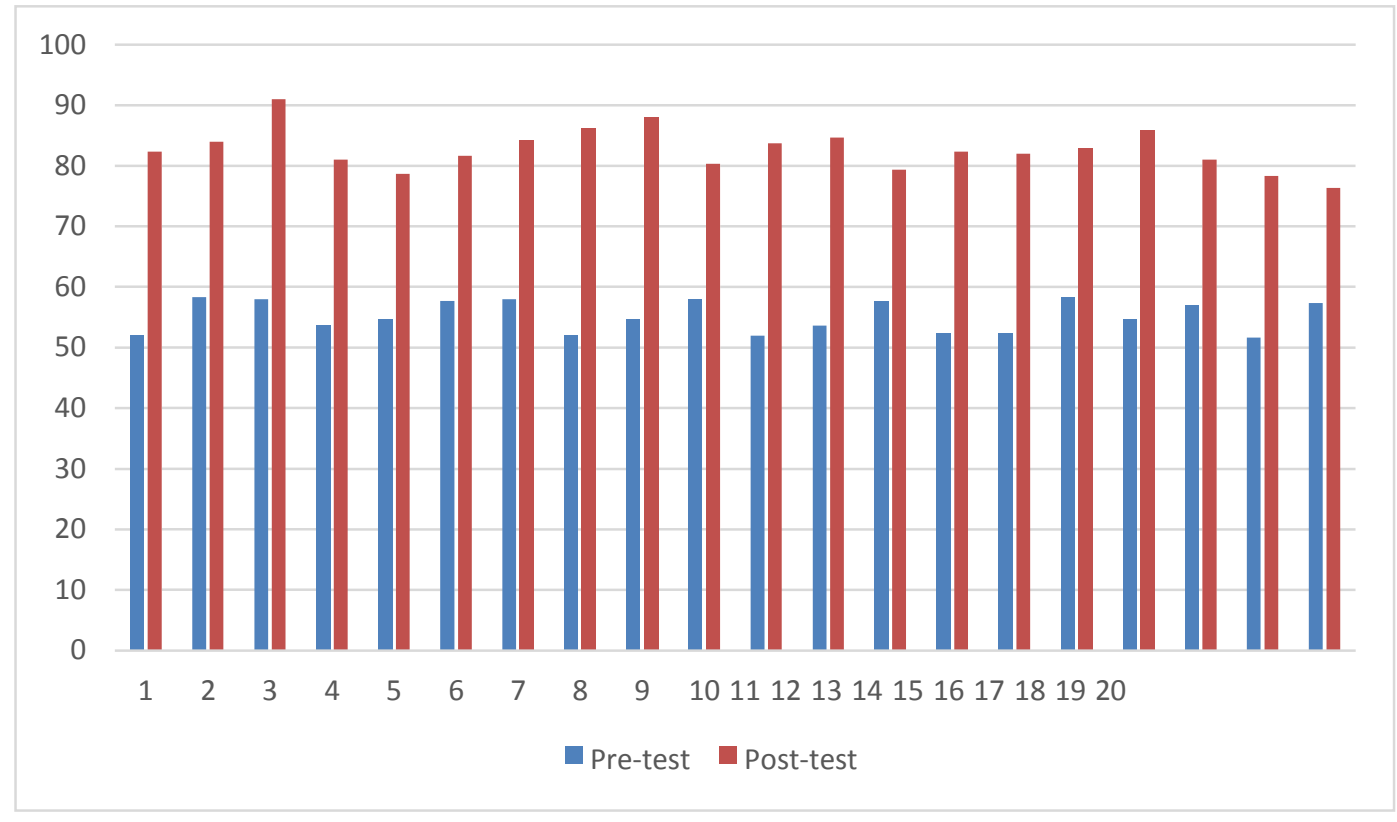

From the chart above, it shows that each student got progress in three category vocabulary building, putting the intonation and speaking fluency. It seems that the implementation of grammar-translation method to teach sentence construction, vocabulary list to enhance the development of vocabulary knowledge, and electronic dictionary to boost the competence in pronunciation influence the students' progress in speaking proficiency. The twenty opportunities of the treatment help the students to develop some supported components in speaking. Nevertheless, this kind of achievement is not the optimum one. It categorized as a useful category based on the rubric. Some further treatments to enhance such a competence need to established.

\subsection{The comparison}

Chart 8. The comparison of the average scores of pre-test and post-test 


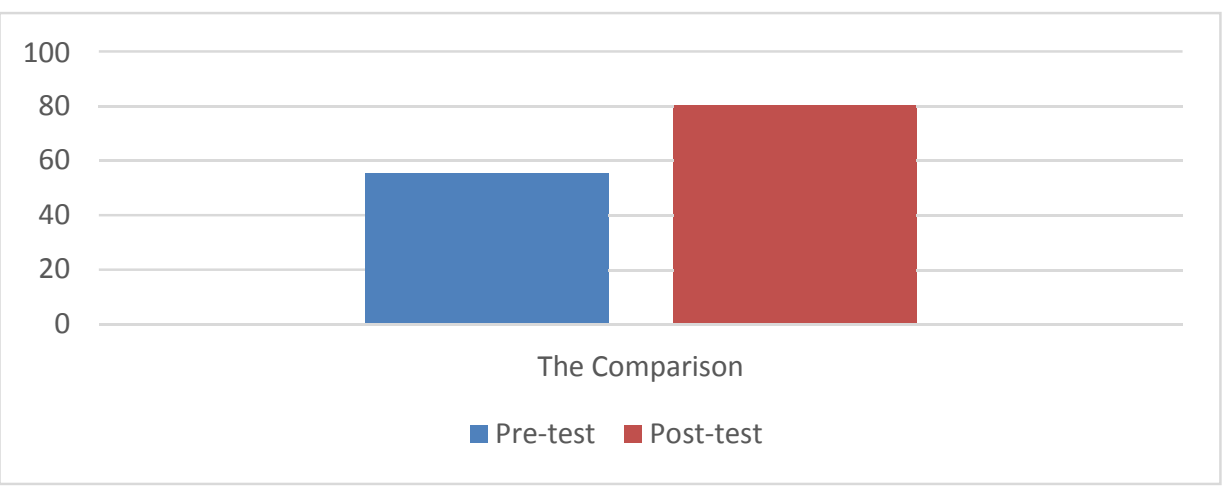

The students get some progress in developing their competence in speaking. Their average score in the pre-test is 52 , and in the post-test is 83 , as seen in chart 8 . They get 31 points of progress. It is $0.31 \%$ of improvement. It means that the implementation of the grammartranslation method and the electronic dictionary can improve the students' competence of speaking from bad to functional categories based on the rubric. It is an excellent effort to assist the students to better their speaking expertise.

\subsection{T-test}

To ensure the result of this study, the implementation of a t-test seems necessary. To implement it, it needs to test the normality of data. It means that the data analyzed should not extreme low or high compared with the average data. The tool like SPSS (Statistical Package for the Social Sciences) application used to see the normality of the data. The two data pre-test and post-test inserted into the process of analysis. It stated that the two data pre-test and posttest have $p>0.05$. It means that the data is in line with the normality norm. The two data passed the normality test, and they are ready to be used for further statistic analysis. The result of the normality test shows in the table below.

\subsubsection{Normality test}

Table 6. Kolmogorov-Smirnov test of normality

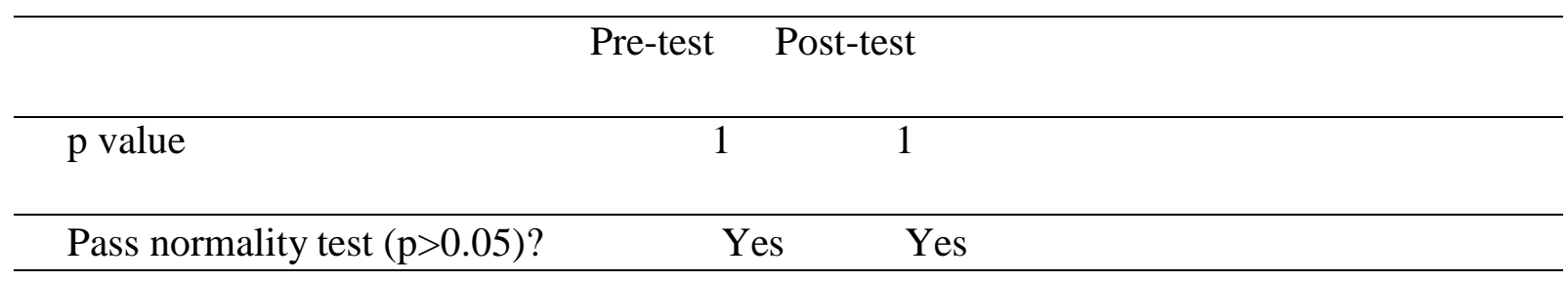

To use of the t-test here is to see whether the implementation of GTM and electronic dictionary affects the development of speaking competence. The hypothesis needs to formulate to start this kind of analysis. The formula appears below.

H0: There is no progress in implementing GTM and electronic dictionary to better speaking competence. $\mathrm{H} 0$ is accepted if $\mathrm{p}$-value $>0.05$

H1: There is significant progress in implementing GTM and electronic dictionary to better speaking competence. Ho is denied if p-value $<0.05$ 
From the analysis of the t-test, it found that the p-value is $<0.0001$. It means that it is less than 0.05. In other words, the hypothesis $\mathrm{H} 0$ denied, and $\mathrm{H} 1$ is accepted. It said that there is significant progress in implementing GTM and electronic dictionary to better speaking competence for the fifth graders. The result of the t-test analysis appears below.

\subsubsection{Paired t-test (compare two data means)}

Col A (Pre-test) vs Col B (Post-test)

Table 7. The Statistic of T-test

\begin{tabular}{lc}
\hline Mean \pm sd of Col A (Pre-test) & $3585000019.400 \pm 2705905902.785$ \\
\hline Mean \pm sd of Col B (Post-test) & $489200.400 \pm 410367.227$ \\
\hline Difference of means & 3584510819.000 \\
\hline C.I. (95\%) of mean difference & \pm 1266441300.398 \\
\hline Lower Range & 2318069518.602 \\
\hline Upper Range & 4850952119.398 \\
\hline
\end{tabular}

$\mathrm{t}$

5.924

$\mathrm{t}$, critical

2.093

p-value

$<0.0001$

Are the means different $(\mathrm{p}<0.05)$ ? Yes

One or two-tailed? Two-tailed

Significance level at $95 \%$

\section{CONCLUSION}

Teaching speaking for EFL young learners is challenging. There are some problems like grammar, vocabulary, and pronunciation that hamper their effort to learn it. It needs some strategies to solve the problems. The use of GTM is one of the ways to help the students understand how to construct sentences. By using bilingual, the students can adapt it to real communication. They dare to raise the questions to the teacher when the explanation of the lesson is not clear. The translation-method from English to Bahasa Indonesia and vise-versa leads the students able to adopt their thought from the two languages into communication. To arrange the sentences, the students need sufficient vocabulary. Providing a list of vocabulary to learn grammar through GTM assists the students in understanding how the sentences

63 | IJET| Volume. 9, Issue 1. July 2020 Copyright 2020 Edy Suseno \& Oikurema Purwati are licensed under Creative Commons Atrribution-ShareAlike 4.0 International License. 
constructed. Moreover, the words the students learn have a specific way to pronounce. They can use the electronic dictionary to find both the meaning and the pronunciation of the word simultaneously. The twenty-opportunity of the treatment helped the students build their supported component of speaking. Through this kind of treatment, it could say that the implementation grammar-translation method and electronic dictionary enhance the development of the students' competence in speaking. 


\section{REFERENCES}

Al-Jarf, R. (2007). Teaching vocabulary to EFL college students online. Call-EJ Online. King Saud University, Saudi Arabia: CALL-EJ Online, 8(2), 8-2.

Al-Seghayer, Khalid. (2005). The effect of multimedia annotation modes on L2 vocabulary acquisition. Research in technology and second language education: Developments and directions, 3, 133.

Bowen, T. (2013). Teaching approaches The grammar-translation method. Online Article: http://www. onestopenglish.com.

Brown, H. D. (2000). Principles of language learning and teaching (Vol. 4). San Fransisco State University: Longman New York.

Bueno, A., Madrid, D., \& McLaren, N. (2006). TEFL in secondary education. Granada: Editorial Universidad de Granada, 4-7.

Cameron, L. (2001). Teaching languages to young learners. Ernst Klett Sprachen: Cambridge University Press.

Carpenter, S. K., \& Olson, K. M. (2012). Are pictures good for learning new vocabulary in a foreign language? Only if you think they are not. Journal of Experimental Psychology: Learning, Memory, and Cognition, 38(1), 92.

Chen, Y. (2011). Studies on bilingualized dictionaries: The user perspective. University, Fujian, China: International Journal of Lexicography, 24(2), 161-197.

DELLER, S. R., \& Rinvolucri, M. (2017). Using the mother tongue: Making the most of the learner's Language. Ernst Klett Sprachen GmbH.

Evans, V. (2006). Cognitive linguistics. George Square: Edinburgh University Press.

Florez, M. C. (1998). Improving adult ESL learners' pronunciation skills. Washington DC:

ERIC, National Clearinghouse for ESL Literacy Education.

Graddol, D. (2006). English next (Vol. 62). British Council in London: ELT Journal.

Hartmann, R. R. (2003). Lexicography: Dictionaries, compilers, critics, and users (Vol. 1). New York: Psychology Press.

Huchinson, T., \& Waters, A. (1987). English for Specific Purposes: A learning-centered approach. NY: Cambridge.

Internet World Stats. (2006). Internet Usage Statistics-The Big Picture: World Internet Users and Population Stats'.

Ioannou-Georgiou, S. (2003). Assessing young learners. Oxford University: Rouledge.

Jafar, F. (2008). The use of English in internet communication by Jordanian students. Aman Arab University: Al-Basaer-A Refereed Scientific, 12(2).

Kaharuddin, A. (2018). The communicative grammar-translation method: A practical method to teach communication skills of English. ETERNAL (English, Teaching, Learning, and Research Journal), 4(2), 232-254.

Krashen, S. D. (2003). Explorations in language acquisition and use. Hanover Street: Reed Elsevier Inc.

Larsen-Freeman, D. (2000). Techniques and principles in language teaching. Great Clarendon Street: Oxford University Press.

Laufer, B., \& Hill, M. (2000). What Lexical Information Do L2 Learners Select in a CALL Dictionary and How Does It Affect Word Retention?. Hongkong University: ERIC.

Nævdal, F. (2007). Home-PC usage and achievement in English. Bergen College: ELSEVIER, Computers \& Education, 49(4), 1112-1121.

Nash, M., \& Donaldson, M. L. (2005). Word learning in children with vocabulary deficits. United Kingdom: Journal of Speech, Language, and Hearing Research.

Nation, I. S. (2013). Learning vocabulary in another language Google eBook. Cambridgeshire: Cambridge University Press. 
Nesi, H. (1999). The specification of dictionary reference skills in higher education. Dictionaries in language learning. Recommendations, national reports, and thematic reports from the thematic network project in the area of languages, sub-project, 9, 5367.

Rapp, D. N., \& Van Den Broek, P. (2005). Dynamic text comprehension: An integrative view of reading. Current directions in psychological science, 14(5), 276-279.

Reach, G. (2004). Global Internet statistics (by Language): Sources \& references.

Rixon, S., \& Council, B. (1999). Young learners of English: Some research perspectives. Bookbarn International US: Longman.

Schmitt, N., \& Schmitt, D. (2020). Vocabulary in language teaching. Cambridge university press.

Scrivener, J. (2011). Learning teaching: The essential guide to English language teaching. Oxford: Macmillan Education.

Singleton, D. (2016). Language and the lexicon: An introduction. London: Routledge. http://www.arnoldpublishers.com

Stockdale, D. A. (2009). Comparing the Perception of Oral Fluency to Objective Measures in the EFL Classroom (Unpublished Thesis). Birmingham: University of Birmingham.

Suseno, Edy. (2019). Bahasa Inggris Untuk Pemula Metode Komik. Yogyakarta: Deepublish.

Tananuraksakul, N. (2015). The Effect Of Online Dictionaries Usage On EFL Undergraduate Students'autonomy. Teaching English with Technology, 15(4), 3-15.

Thornbury, S. (2006). How to teach vocabulary. India: Pearson Education.

Ur, P. (2008). A course in language teaching. Ernst Klett Sprachen: Cambridge University Press.

Walters, J. (2004). Teaching the use of context to infer meaning: A longitudinal survey of L1 and L2 vocabulary research. Language Teaching, 37(4), 243.

Wood, J. (2001). Can the software support children's vocabulary development?. Language Learning \& Technology Journal, 5(1), 166-201.

66 | IJET| Volume. 9, Issue 1. July 2020 Copyright 2020 Edy Suseno \& Oikurema Purwati are licensed under Creative Commons Atrribution-ShareAlike 4.0 International License. 